\title{
TWO RESIDUAL NOTES ON MODERN ARAMAIC OF HERTEVIN
}

\author{
Yoshiyuki TAKASHINA*
}

\section{Introduction}

The first report of the existence of Modern Aramaic (MA) of Hertevin (H) published in 1971 by Otto Jastrow(1) was indeed great news to those who are interested in MA studies. The importance of this dialect is almost selfevident because its linguistic structure shows quite a different set of features as a whole from any of the MA dialects hitherto known, but the problem is the position for it to occupy among MA. In my recent study (Takashina forthcoming), it is argued that it should form an independent group of its own comparable to Modern East Aramaic (MEA), Modern Central Aramaic (TTūrōyo), Modern West Aramaic (Ma'lūla) and Modern Mandaic. The argument is based chiefly on the verbal system of $\mathrm{H}$, especially on the forms that correspond to the passive participle as well as the infinitive in Late Aramaic that play a significant role in the verbal system of all MA languages. (2)

This paper deals with two remaining points left from the preceding study and discusses them more elaborately.

\section{The Phrase $\sqrt{ }$ mḥy 'To Strike' + bala 'Mind, Heed'}

In Takashina forthcoming, I cited the following sentence as an example of Passive construction, (3) but one is at a loss how Jastrow understands it because of his two different translations. In order to obtain a precise understanding of this sentence, we sholuld look to the other examples of this phrase for the clarification of its syntactic structure.

1) 'ad mehya bal-o l-šarq(509)/Meșser (511)/baḥha(510) (4)

'that (she-camel) which has been turned to the east/Egypt/here'

'diejenige, die nach Osten/Ägypten/hier ausgerichtet war'

* Assistant Professor, Osaka University of Foreign Studies.

Vol. XXVI 1990 
'sie hat sich in Richtung Osten gewendet'(5)

As soon as we get other instances of this phrase together, we are almost perplexed at its variety of usages with ramified meanings according to the context. On a careful analysis, however, it turns out that these seemingly bewildering semantic ramifications depend on what the direct object of the verb ل $m h y$ 'to strike' is (bala 'mind, heed' or something else), and on the syntactic role of bala. Besides 'the definite direct object agreement rule' (DDOA rule)(6) makes the surface structure of the sentence all the more complicated. Before going into the detail, it would be better to cite an ordinary sentence of this verb.

2) 'amma 'emm-et (<-ed) hatha mhe- $\phi$-wa

berqa,

but with-of thus strike(RESULTATIVE)-he-PAST lightning

b-qudart-et $(<-e d)$ 'alaha, mhe-wa berqa l-bahtonta (340)

by-might-of God it strike-PAST lightning to-woman

'but suddenly a lightning has struck, by the might of God, the lightning

had struck the woman'(7)

In regard to the gender of bala, which is indispensable in the following discussion, we can make sure that it is masculine, as is shown in the next example. (8)

3) 'alaha meš mat'ér-re(<-le)-le bal-ew 1 -Yosep(477)(9)

God again turn(PERFECTIVE)-he-it(OBJECT) heed-his to-Yosep

'God turned his heed again to Yosep.'

The first $-l e$ is a Pronominal Suffix (PS-C')(10) for the subject referring here to God while the second -le is PS-C that indicates the object, which is incorporated now into the inflection to refer to bal-ew in accordance with DDOA rule. Seeing -le of PS-C is a suffix for the third person singular masculine, the noun bala it refers to is masculine.

Now the result of my analysis is presented here according to the syntactic structure of the sentences. These instances are all we have in Jastrow's Texts that employ this puzzling phrase. Symbols used are: $\mathrm{V}=$ $\sqrt{ } \mathrm{mh} y, \mathrm{~S}=$ subject word, $\mathrm{O}=$ object word, $\mathrm{D}=$ word indicative of the direction of 'heed', []$=$ word boundary, $+\mathrm{S} / \mathrm{O} / \mathrm{D}=$ pronominal suffix attached to the preceding verb or to bala in the form of PS-B or PS-C to refer to S/O/D.

(I) Object $=$ bala

A. $\mathrm{S}-[\mathrm{V}(+\mathrm{D})]-$ bala $-[1-\mathrm{D}]$ 
'S strikes (S's own) heed to $\mathrm{D}>\mathrm{S}$ pays heed to $\mathrm{D}$ '

4) 'áțtore tob l-šăbola, l-qyama la mhe-la

then any-more to-blooming, to-standing not strike(PERFECTIVE)-she

bala. (211)

heed

'then it [=tetton(f.) 'tobacco plant'] did not pay heed to blooming or growing tall any more'

5) 'ahni le mahe-le

l-Sațana bala (372)

they not strike(IMPERFECTIVE)-it(OBJECT) to-Satan heed

'they do not pay heed to Satan'

Evidently these two sentences form one group. Therefore the object PS -le in the second example cannot refer to bala in view of the fact that it does not appear in the first example. This means that it refers to Satan. The context shows that Satan is definite having been introduced before this sentence, while qyama is introduced here for the first time. Though these words correspond to the indirect object in our understanding, 'to strike heed' seems to have become an idiomatic verb phrase and thus their superficial indirect object has approached the syntactic function of the direct object. So the employment of PS -le is in proper accordance with DDOA rule.

B. $\mathrm{S}-[\mathrm{V}+\mathrm{O}]-[\mathrm{bal}+\mathrm{S}]$

'S strikes S's own heed (to S-self) $>$ S makes up S's mind'

6) mhé-la-le bal-o (374)

strike(PERFECTIVE)-she-it(OBJECT) heed-her

'she made up her mind'

7) mhoówen-ne $(<l e)$ bal-ehon, sayyon

strike(IMPERATIVE PLURAL)-it(OBJECT) heed-your, go(IMPERATIVE PLURAL)

l-Meșser (511)

to-Egypt

'Make up your mind, go to Egypt'

PS - $l e$ is obligatory in this case according to DDOA rule because bala takes a possessive PS without fail, and D is not necessary since the heed is directed to the subject.

(II) Object $=$ Animate

When an animate noun already referred to in the previous sentence is Vol. XXVI 1990 
the object of the verb, DDOA rule requires PS-C in the verb, whereas $b a l$-S/O and $l$-D form a so-called circumstantial clause in subject-predicate relation.

C. $\mathrm{S}-[\mathrm{V}+\mathrm{O}]-[\mathrm{bal}+\mathrm{S}]-[1-\mathrm{D}]$

'S strikes $\mathrm{O}$ with $\mathrm{S}$ 's own heed to $\mathrm{D}>\mathrm{S}$ makes $\mathrm{O}$ set out for D'

8) mhé-le-le bal-ew l-Meșșer, zi-le (444 twice)

struck-he-it(OBJECT) heed-his to-Egypt, went-he

'he made it [=sanduqa 'box' in which Yosep is hidden] set out for Egypt, he went'

9) mhéele-la

$$
\text { bal-hen l-Meșser (512). . .zi-le }
$$

struck-they-her(OBJECT) heed-their to-Egypt go-they

l-Meșser (513)

to-Egypt

'they made it $\left[=\right.$ the people of the city $\left.\operatorname{mdita}\left(\mathrm{f}_{\text {. }}\right)\right]$ set out for Egypt. .. and they went to Egypt'

Considering the inchoative implication of this structure, it needs $\sqrt{ }$ ' $z l$ 'to go' after it. In the latter example the subject marker -le is the shortened free variant of the third person plural -lehen as we can see from the possessive PS -hen. (11) So it may be that $z i-l e$ in the first example means 'they went'. D. $\mathrm{S}-[\mathrm{V}+\mathrm{O}]-[\mathrm{bal}+\mathrm{O}]-[\mathrm{l}-\mathrm{D}]$

'S strikes $\mathrm{O}$ into the result of O's heed turned to $\mathrm{D}>\mathrm{S}$ turns O's heed to $\mathrm{D}>\mathrm{S}$ turns $\mathrm{O}$ to $\mathrm{D}^{\prime}$

10) mhé-le-la bal-o l-šarq/Meșser/baḥha =šumala (508)

struck-he-her(OBJECT) heed-her to-east/Egypt/here=north

'he turned her(she-camel) to the east/Egypt/here=north'

From the preceding passage we know that the she-camel cannot move because it has been tied to something else.

E. $\mathrm{S}-\mathrm{V}-[1 /$ batr $-\mathrm{D}]$

'S strikes (S-self) (with S's own heed) to D $>$ S sets out for D toward/ after D'

11) $m h$-ah(-hek) l-țra, $\quad$ ' $i z-a h$

strike(RESULTATIVE)-we to-mountain, and go(RESULTATIVE)-we ptil-ah (431)

roam (RESULTATIVE)-we

'we have set out for the mountain and have gone [and] roamed' 
12) mdita mhe-la batr-ehen (512)

city(f.) strike(PERFECTIVE)-she after-them

'(the people of) the city(f.) went after them'

When the object is the same as the subject and the bala is S's, then they both are deleted. So this is the variation of the construction $\mathrm{D}$, meaning 'S turns himself to D', and it does not imply any movement from the spot. Hence we find 'to go' or a similar expression after it. Even in the latter instance that lacks it in the same person, gender and number, we read 'they went' after it.

To turn back to the first example with the result of this analysis in mind, its structure is presented as follows.

13) meh̆y-a bal-o l-šarq(509)/Meșẹer(511)/baḥha(510)

strike-she heed-her to-east/Egypt/here

Whether the verbal form is Resultative (=active) or Passive, its structure will be: $\mathrm{S}-\mathrm{V}-[\mathrm{bal}+\mathrm{S}]-[1-\mathrm{D}]$. The nearest one to this may be the structure $\mathrm{C}$ above, but it is an ill-grounded haphazard comparison in that the verb in 13) lacks PS -le to refer to the definite object bal-o. To put it otherwise, DDOA rule is not observed in 13) and this affords so indubitable a proof as to rule out any possibility that this sentence may be an active Resultative. The context also supports this. Hence this should be taken as a Passive construction corresponding to the structure D. Indeed the example 10) is its active counterpart whose object '-la (=her)' has undergone passivization to produce 13).

Apart from this complicated phrase, it is not too much to say that this confusion has been brought about by the innate ambiguity this verbal form has. As Jastrow has said with good reason, the Resultative has not been fully integrated in the verbal system of $\mathrm{H}$ yet. ${ }^{(12)}$

\section{Nouns in Construct State in MEA}

It has been argued in Takashina forthcoming that the ending -ed of nouns in the genitive construction of $\mathrm{H}$ has its origin in the Late Aramaic construction *-eh $d$-: $\mathrm{NOUN}_{1}$-eh d-NOUN ${ }_{2}$ 'NOUN 1 of $\mathrm{NOUN}_{2}$ '. Though this -eh 'his' refers to $\mathrm{NOUN}_{2}$ (masculine singular) in the original Late Aramaic, the construction was so widespread that it has been generalized to the other gender and number also. This syntactic feature is likewise observed in the 
case of prepositions of nominal origin when it governs the following noun. This feature is restricted to nouns of Aramaic etymology and Aramaicized ones whose ordinary form ends in $-a$ (singular) and $-e$ (plural). (13)

Thus it has been stressed that this ending is to be regarded as that of a new construct state peculiar to the nouns in the genitive construction as opposed to the nouns that do not stand in such a relation with other members of the sentence. To prove that this is not an isolated phenomenon in $\mathrm{H}$ alone, very similar syntactic parallels have been quoted in my paper from Aradhin, Zakho, Nerwa, Azerbaijan and Salamas(14) but I have not dealt with the case of $\mathrm{U}$ in detail.

As the texts of these dialects show, the extent to which this phenomenon is generalized seems to vary from one dialect to another and the rule has not been fixed yet concerning its phonological and syntactical usage apart from Aradhin and Azerbaijan. It would not be too much to say that Nöldeke was fortunate in having the Salamas text before him which was written almost as it is spoken, though written in Syriac script, when he identified this feature in the dialect for the first time. ${ }^{(15)}$ Tsereteli, who discussed this feature in detail, also knew the living Aramaic dialects spoken by the native speakers in USSR, including Urmi.(16) I mention this because the quasihistorical spelling of Syriac script does not reflect the real pronunciation of Urmi in general, and overclounds this feature in particular. This phenomenon has also been left unheeded even in the 'New Alphabet'.

Since we now know, however, that Urmi also shares this feature in their real speeches thanks to the study of Tsereteli, we must look into the relationship between the orthography and the real utterances shortly after the introduction of the orthography and how scholars dealt with it.

As is well-known, the quasi-historical spelling of MEA of Syriac (Nestorian) script was 'invented' by the American missionary Justin Perkins shortly after he arrived at Tabriz in 1834 and began to learn Urmi dialect from the two native speakers: Mar Yohannan (a bishop of Urmia) and Abraham (a priest of Urmia). (17) Hence when he began to teach only seven boys at first in their vernacular using a manuscript card suspended on the wall (January 18, 1836), his orthography also began to spread among the natives. This was greatly accelerated by the arrival of a printing machine at Urmia (his missionary center) in 1840, which printed 'more than eighty thousand volumes, comprising more than fifteen millions of pages.'(18) Other 
missionary groups also produced printed materials, though in an orthography slightly different from each other.

According to the first grammar of this dialect written in a European language by David Tappan Stoddard, (19) this orthography, however, underwent an important change that concerns our present discussion to a great extent. He writes (1856:26): "In our books we have often written -eh as a nounsuffix for $3 \mathrm{~d}$ pers. sing. masc., and -ah for $3 \mathrm{~d}$ pers. sing. fem., eg. bêt-eh his house, bett-ah her house. We now substitute for these, in all nouns, why [properly -u] and $w h$ [-o], in accordance with Oroomiah usage. ..... We have also, in such expressions as brûn-eh $d-n \bar{a} s \bar{a}$ [Son-his of Man], dropped the suffix which is employed both in Ancient Syriac and in Chaldee." (Italics are written in Nestorian script in the original and brackets are mine.) This means (1) that they replaced the 3rd person singular pronominal suffix $-e h /$ - $a$ h by the proper Urmi form $-u /-o$ and (2) that they gave up using the genitive construction of Classical Syriac in favor of a simple preposition $d$ 'of'. (20)

Though I am ignorant what particular reasons caused them to do so, it was a necessary change to keep their texts conformable to Urmi dialect now that their missionary activities gained a firm ground in the Urmia region. Since Stoddard writes the above remark in 1853 , the revision must have been made accordingly in the second edition of the Bible (NT 1846 and $1854^{2}$; OT $1852^{1}$ and $\left.1858^{2}\right)^{(21)}$ But strangely enough this readjustment of the spelling seems not to have been thoroughgoing, as is evident from the versions (1910 and 1966) in my possession. ${ }^{(22)}$ One example will be enough for the present purpose.

14) u kad db-la d tijva va (tijviva) $b$ [l-supra go] bet-eh (beto) $d$ prijşa, şqil-la şaţbpta d bisma u kli-la bar-eh (bar-u) lkis aqlat-u [aql-u].

(Luke $7: 37-8$ )

'when she-knew that he was sitting [at-table] in the house of the Pharisee, she-took a box of ointment and she-stood behind-him at hisfeet.'

Since this text is quoted, exactly as printed in 1910, in the Biblical commentary published in their monthly periodical Zahrir $\bar{e} d B a(h) r \bar{a}$ 'Rays of Light'(23) vol. $34 / 11$ (1882):46-7, the text is undoubtedly the one after the revision, as is exemplified by the use of $-u$ 'his' in both versions in aqlat-u $[a q l-u]$ 'his feet'. Here the difference lies only in the choice of the plural Vol. XXVI 1990 
forms $a q l$-ati/aql-i for aqla 'foot'. So the type of revision (1) above is achieved.

The other type of revision (2), however, is left out, deliberately or not, as in bet-eh $d$ prijşa which would, after the revision, be beto $d$ prijşa 'the Pharisee's house'. Again the form bar-eh puzzles us for Urmi should have bar-u 'behind him' instead. ${ }^{(24)}$ That this former form is not of Urmi is demonstrated beyond all question by the text of Stoddard himself (1856:179).

15) ino judəji ţaujbj-vo bar-u b ido (John $7: 11)^{(25)}$

'but the Jews were-searching after-him at the feast'

Seeing that this text is paralleled by the 1910 version exactly, this should be regarded as the revised text. We are, however, at a loss with two forms $b a r$-eh and $b a r$-u in the same edition of NT. Incidentally the verbal form tijva va (example 14) also betrays the bewildering nature of the Biblical translation, because the literary style of Urmi would have tijviva [-ve:-] (<tijvo (participle) + ijvo (past copula)) 'he had sat and was sitting' (Resultative past) for it. Copulas can be deleted in the subordinate clause, to be sure, but it never becomes va.(26) So the question arises what the nature of this $v a$ is and how the form -eh stole into the text that is claimed to be based on Urmi.

It is more than natural that the Biblical text intended for the people who speak various dialects differing from one another in the mountaneous region of Kurdistan should reflect some sort of compromise in its orthography. Though Perkins' teachers of the language were natives of the plain of Urmia, he was assisted in the translation also by four other men from the mountain, ${ }^{(27)}$ i.e., the region of 'III. The Ashirat Group' of Maclean. (28) This Group includes among others the dialects of Tkhuma and Upper/Lower Tiari, which have -e for 'his' as Table 7 of Takashina forthcoming shows. The only grammatical description of Tkhuma by Jacobi generally exhibits two or three variants for most of the linguistic forms and this may be accounted for by the fact that the dialect described is the one situated on the River Chabur in Syria where most of the tribes settled after the severe hardships they had to suffer. In the face of variants, one of which parallels to Urmi while the other to the Mosul group, one wonders if this may be the result of dialect mixture though it may have been the case also before the emigration from the homeland. Be that as it may, the Resultative past is given as follows: 'iwa griša grǐša 'îwa griša-wa 'he had pulled/it has been pulled'(29). The last 
of the three variants can explain the from tijva va cited above, namely, $i j$ $\left(=^{\prime} i\right)$ of the past copula may be dropped when it is suffixed to the predicate, as against the Urmi where [e:] results from $-a+i j$.

If this is the from of the native dialect of the four priests mentioned above, we cannot blame Perkins for having produced a 'denationalized' or 'too Classicized/historical' text of the Bible simply because the text does not always conform to the Urmi dialect. His revised version of the Bible is basically Urmi with occasional connivances of the traits peculiar to the dialects of the mountains which the area of his missionary activities comprised. Whether these leftovers are due to Perkins' deliberation or too heavy pressure of the missionary work is beyond our concern. At least it is to be presumed, however, that it was not 'usually spelt by error (my italics) in the printed books $(h) w \bar{a}$ '. ${ }^{(30)}$

What will be the actual form of the nouns in the genitive construction and how did the scholars in the preceding century deal with it, then? It is to be recalled that while missionaries were dedicating themselves in the difficult conditions that claimed not a few lives of the staff, some of European scholars devoted their concern to the study of MA on the basis of what information they got from the missionaries or travellers and some even undertook a research trip to the Middle East. It was about this time that a certain native speaker of Urmi dialect, called Ōdī̌su bar Arsānis from Matmaryam near Urmia(31) came to Germany.

To the best of my knowledge Merx (1873) was the first to study his native pronunciation. Until then scholars were obliged to study MEA only through the texts written in Nestorian script 'revived' by the missionary. Since it was a quasi-historical orthography, the actual pronunciation had been blurred and this difficulty is expressed straightforwardly by Nöldeke. If he had met Giwárgis bar Húrmis from Urmia earlier before the completion of his grammar, the situation of MEA studies would have been quite otherwise.(32) But, as it was, the contribution of Merx should be valued all the more. At the end of his Lesebuch (pp. 57-64) he gives us a transcription of Ōdišu's pronunciation alongside of the texts in Syriac script (the first chapter of Luke and two poems). Seeing that the text of the Gospel is that of the revised version (my 1910 edition), we can compare the text and actual pronunciation even if the text is of 'artificial' nature. In these instances the sequence of $-e h d$ is pronounced as [it $\sim \mathrm{id}]$. 
16 a) brun-eh $d$ bllaja (Luke $1: 32$ ) 'the son of the High'

$=\mathrm{T}$ brúnit 'illáya(33)

16 b ) bet-eh Jaqu (1:33) 'the house of Jacob'

$=\mathrm{T}$ beti d'Yáku

16 c) ijd-eh $d$ marja $(1: 66)$ 'the hand of the Lord'

$=\mathrm{T}$ idi dě marya

$16 \mathrm{~d})$ nvij-eh $d$ bllaja (1:76) 'the prophet of the High'

$=\mathrm{T}$ nĕbiyyi dě 'elláya (sic)

16 e ) pat-eh $d$ marja (1:76) 'the face of the Lord'

$=\mathrm{T}$ páti dĕ márya

As against this, the transcription furnishes us with two very suggestive cases where the pronunciation [et $\sim$ ed] is recorded while the text is written $-a d$, that is, without -eh.

17 a) libba $d$ avahi $(1: 17)$ 'the heart of the fathers'

$=\mathrm{T}$ libet babawáti(34)

$17 \mathrm{~b})$ ijdo $d$ dişmin-an $(1: 74)^{(35)}$ 'the hand of our-enemies'

$=\mathrm{T}$ 'ide dĕ dišminnan

In view of the fact that there are cases where the same sequence $-a$ $d$ is transcribed simply as [-a dě], it may safely be said that the examples (17) betrayed the informant's actual pronunciation against the text he may have read with the Bible before him. This explains his rather artificial sound [it id], since -eh is phonetically represented by [i] in Urmi. ${ }^{(36)}$ In his normal speech it would be [et $\sim$ ed].

On the other hand this defect of ambiguous nature of the transcribed text is totally free from Albert Socin's work (1882). As luck would have it, Merx' work (Tübingen, 1873) appeared first whereas Socin and his friend Hoffmann had engaged in the research of the language of Ōjišu in Berlin at the advice of their teacher $\ddot{A}$. Rödiger shortly after the publication of Nöldeke's grammar (1868). But as he discovered Modern Central Aramaic (Ṭūrōyo) in Damascus in March 1869 during his scientific trip to the Middle East and presumably devoted himself to the preparation of the material for printing (published in 1881), his former study of Urmi texts was published only in 1882.(37) Thus his linguistic competence as field worker is reflected well in his method of recording the materials. ${ }^{(38)}$ So his transcription can be relied upon fully in our discussion. The examples are from his Text XIII. 18 a ) babo $d$ oho brato $(90: 14)$ 'the father of this daughter' 
= T bábe dā brắta (91:14)

18 b) odana d davbj (90:15) 'a doer of a quarrel $>$ a quarrelsome man' $=\mathbf{T}$ ò-dấnet dáwih $(91: 15)$

$18 \mathrm{c}$ ) bi bəbə d jələ $(90: 20)$ 'the household of the father of the youth' $=\mathrm{T}$ bibábet yálā $(91: 20)$

It is only natural that the text of Syriac script has no instance of -eh $d$ and [et ed] corresponds to the orthography $a d$, while on the contrary in the Hoffmann's part $-a d$ is always transcribed as [at ad].(39) This reflects the difference of the methodology of the two.

A little later G. Kampffmeyer studied with Mansur from Urmia in Berlin (1896) and published some proverbs collected from him (1905). Although his transcription of 108 proverbs does not show so clear a picture as Socin's, yet we find several instances of our concern of which I list here explicit ones. ${ }^{(40)}$

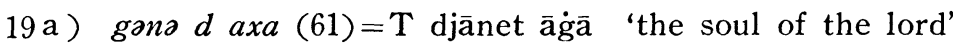

19 b) rişa $d$ gan-ux=T rišě djānŭh (sic) 'the head of your-self'

To the important studies by Russian scholars, especially that of Kalašev (1894), I could not have access. (41) Since then, in many other works of MA the phenomenon of Urmi in our discussion seems to have been neglected, and it is $\mathrm{K}$. Tsereteli, who engaged himself in the vigorous study of MA, that resumed this problem for the first time since Nöldeke. In his study of various types of genitive construction in MEA (1965b), he discussed this phenomenon, too. His presentation of the argument, however, seems to be a little confused. If he explains the nature of -it of bet-it mälkä 'king's house' according to the type $\mathrm{NOUN}_{1}+$ pronominal suffix $+\mathrm{d}+$ $\mathrm{NOUN}_{2}$, which in itself is quite convincing, he should not have listed instances like yimit pōha ( $\left\langle y i m a d^{e}\right.$ pōha) 'mother of the wind' under the type NOUN $_{1}+d+$ NOUN $_{2}$. ${ }^{(42)}$ One would misunderstand he tries to derive the former -it from-eh $d^{e}$ and the latter -it from $-a d^{e}$.

Apart from his many important contributions to MA studies, what counts most in this line of argument is the recording of the bulk of Urmi texts. He published a collection of the texts (1965a) in the dialect spoken by the immigrants from the village Nazi not far from Urmia living now in Dzveli Kanda (Georgia), which he recorded in 1944 and 1961-2. This collection merits a special attention in that this is the only texts of some length put down directly from the actual normal speech without a written 
source that would affect the speech of the speakers. In these texts the first member of the nouns in the genitive construction usually ends in -it. Only two examples from the very first page of the collection will suffice. ${ }^{(43)}$

20 a ) tämäšit bnätit mälkä (2:17) 'the (wonderful) spectacle of the king's daughters'

=tamaşa d bnoti $d$ molko

$20 \mathrm{~b}$ ) brätit årătịh $(2: 19)$ 'the daughter of the middle (neither elder nor younger)'

$=$ brata $d$ aralix(4)

Though the text is noted in too narrow a transcription in my view, the intrinsic value of this work turns out immediately when we turn to Cerulli (1971) for this phenomenon because this provides us an equally long texts written down in transcription in modern times. The text of the latter is said to be collected 'dalla viva voce', ${ }^{(45)}$ yet we can find no instance for it even in the parts that are not accompanied by the corresponding Nestorian orthography. ${ }^{(46)}$ So we are obliged to assume that the informant was an educated person, or that the ordinary speech of Assyrians in Iran has been so affected by the literary language, which having been invented first by the American mission has now become the koine among the Assyrians all over the world(47), as to show little difference from the literary language when speaking in public at least. On the other hand their compatriots in Russia, from whom Tsereteli recorded his material, could retain the innate traits of their vernacular since they had been less exposed to printed texts.

$\mathrm{Be}$ that as it may, as we have seen above, either an insufficient methodology of the work or the growth of the literary language as lingua franca of Assyrians have hindered this phenomenon from being noticed which must have existed in the actual utterances, except in the studies of Socin, Tsereteli and some others. It may be precisely due to this that the instances escaped my cursory reading of the texts in other works not mentioned above.

As to the generalization of [it et $\sim$ ed] for the original $*-e h d$ (when $\mathrm{NOUN}_{2}$ is masculine) to the cases where it is feminine or plural, or to the cases where $\mathrm{NOUN}_{1}$ is plural and ends in $-i$, after [it et $\sim$ ed] has been fixed as a usual ending in the genitive construction $(-a d)$, we find no difficulty to account for as seen in the examples quoted above.(48) This ending can occur even when a prepositional phrase or a nominal clause comes 
in place of $\mathrm{NOUN}_{2}$ when these are perceived as forming a genitive construction. In the case of independent personal pronouns and demonstratives, we are told that a 'doubled' genitive(49) is formed. But this is simply because those pronouns take $d$ before it when they come after prepositions and, prepositions being nominal in origin, pronouns with $d$ prefixed to it have come to be felt as a usual form to stand in the position of $\mathrm{NOUN}_{2}$. ${ }^{(50)}$ It is by no means 'doubled' in the syntactic structure, but it is the sound [d] that appears twice.

Thus to conclude this article, I may be permitted to conjecture that the first introduction by Perkins of -eh 'his' in his Nestorian orthography was not without ground. When he learned Urmi from his informants, he must have heard [et ed] of the genitive construction since their speech had not been 'contaminated' by the script yet, when he was reminded of the similar construction in Classical Syriac. This similarity to the classical language, as well as the corresponding form $/ e /$ of the dialect of the translators from the mountain, lead him to adopt this form for 'his'. Considering that he was such a thoughtful and strenuous person as to have attained his aim in the hardships, it is to be doubted that he did not know $-u / o$ for 'his/her', how to spell set apart. When he knew that the ground for his mission became firmer in Urmia, he chose to readjust the style to be in more conformity with the normal speech of the place of his center and began to revise the first edition of the Bible. He may have decided to leave ecclesiastical phrases as they were, in favor of classicism, but 'unfortunately' some others had also been overlooked by the translators from the mountain. Irony is, however, the fate of this written language adapted to fit better with one dialect, which now threatens many others left unrecorded even today.

\section{Notes}

(1) Jastrow 1971. He published a full description of $\mathrm{H}$ recently (1988).

(2) Hoberman classifies it as an independent subgroup of MEA (='Northeastern Neo-Aramaic' in his term). See Hoberman 1989: 4, 6 and Table 2 on page 7.

(3) Section 3.1.1. Verbs (1): Tense/Aspect System, example 37).

(4) Numbers after the citation refer to the passage numbering given in the Texts of Jastrow 1988: 108-75. Citations from his Texts are somewhat simplified for brevity's sake and the sign for glottal stop is changed to the apostroph.

(5) Jastrow 1988: 157, 159 and 215. The latter is what he gives for the citation without a relative 'ad.

(6) Hoberman 1989: 102 introduced this rule for the Jewish dialect of Amadiya. Krotkoff 1982: 28-9 has termed a similar phenomenon in the dialect of Aradhin as 
'the object conjugation'.

(7) For the terms of the verbal system in $\mathrm{H}$ the following are used (those in brackets are Jastrow's): Imperfective (Präsens), Perfective (Präteritum), Resultative (Perfekt), Past Perfective (Plusquampräteritum). See Takashina forthcoming, section 3.1.1. verbs (1) and Table 5. Some of the other examples of this verb are listed in Jastrow 1988: 215.

(8) Though the word is of common stock in Aramaic, this confirmation is very important seeing that the gender of some nouns switches from the one to the other in MA dialects.

(9) This seems to be the only instance of bala that enables us to check its gender. Almost the same phrase is to be found once again in the same passage 477 and twice in 474 .

(10) The subject marker for the Perfective base is usually PS-C (my term; the set is listed in Jastrow 1988: 50-1), but when the Perfective takes an object a slightly different set PS-C' (op. cit. 61) takes the place of it and leaves PS-C to show the object. In the case of the third person the two are the same. For the full set of PS's see Takashina forthcoming Table 2 .

(11) Jastrow 1988: 50-1.

(12) Jastrow op. cit. 59.

(13) Takashina forthcoming: sections 3.8 and 3.10. For the full description of the rule see Jastrow 1988: 25-6, and 102.

(14) By Salamas here I refer to the text of Catechismus (Rödiger 1839; cf. Takashina forthcoming: section 3.8. and note 84.). Nöldeke $1883: 598$ identifies it as written in the dialect of Salamas, which is the very first text scholars knew of a living Aramaic still spoken in modern times.

(15) Nöldeke 1868: 148-9. We must recall that the Catechismus had been written by the year 1827 (Rödiger 1939) before J. Perkins, the inventor of the Urmi orthography of Syriac script, arrived in Kurdistan in 1834. See Macuch 1976: 107+116ff. and the journal of Perkins (1843).

(16) Tsereteli 1965b. See below for the importance of his work 1965a.

(17) Perkins arrived at Tabriz on August 23, 1834 (not August 28 as given in Macuch 1976: 118, see Perkins 1843: 142 and 1862: 7). He went to Urmia and brought them back to Tabriz as his teacher of the language and cooperator in his missionary work. Incidentally Mar Yohannan, resident of a village called Gavalân northeast of Urmia near the Lake, is the very person who intrusted, in the spring of 1825, his manuscript of the Gospel in Nestorian script with Joseph Wolff to receive duplicates in return. This was reproduced as the first Nestorian Gospel printed in London in 1829 and when Perkins arrived at Tabriz he found a box of the copies of the Gospel had arrived there (see Perkins 1862: 8-9, Stoddard 1856: 5 and Macuch 1976: 201-2). Likewise when Eli Smith and H. G. O. Dwight of the American Board of Comissioners for Foreign Missions, stimulated by the report of Wolff published in an English paper, met him in their search for Nestorians in the spring of 1830, Yohannan gave them general information of Nestorians in the region. [It was these missionaries who obtained the text of Catechismus referred to in notes (14) and (15).] Abraham, chosen by Yohannan as his 'scrvant', was a young priest living in the village of Gěog-tapá, southeast of Urmia. Thus the language teachers of Perkins happened to be native speakers of Urmi dialect. See Perkins 1843: 172-7 and 188-9.

(18) Perkins 1843: 250 and $1862: 13$. 
(19) He accompanied Perkins in a new reenforcement when Perkins returned to Urmia from America in the spring of 1843. See Perkins 1862: 16. His grammar was completed in 1853 and appeared twice, first in London 1855 and again in JAOS 5 (1856) : 1-180h. He had also revised 'A Spelling Book' (Ktābaā d-huggāyā) written first by A. L. Holladay. See Macuch 1976: 131 and Stoddard 1856: 6 .

(20) For the spelling of $-u /-o$ see Polotsky 1961: 16-7.

(21) Macuch 1976: 126-7.

(22) The 2nd Urmia edition of NT was reproduced in New York 1886 (Macuch 1976 : 127). It was printed repeatedly by American Bible Society and mine is its 11 th edition (1910). The other one $(A T+N T)$ is published by The Bible Societies in The Near East in Beirut 1966. Seeing that the texts of both versions agree mostly with minor differences between them, it is certain that the latter derives from the former, but I am not sure of its exact history of textual redaction. As regards the point in our discussion there seems to be no difference. They are referred to by the year of publication 1910 and 1966. The text of 1910 is cited in the 'New Alphabet' spelling and the text of 1966 is given in square brackets for the underlined part of 1910 where they differ. The ordinary (literary) form of Urmi is given in round brackets. Hyphens show constituent analyses for the understanding of the text. The form in question -eh/-u is left unitalicized.

(23) For this monthly see Macuch 1976: 136ff.

(24) Though self-evident, Maclean 1901: 41b gives the form explicitly for Urmi.

(25) The 1966 version has ill-i spelled il-eh 'for him' instead of bar-u.

(26) Maclean 1895: 145 ( $\$ 56$ pluperfect) and Marogulov 1976: 89-90.

(27) According to the summary of an article in "Rays of Light" vol. 48 (1897) given in Macuch 1976: 74, they were Ǐšo‘, Denḩā, Ishāa and Tammū. The second priest figures in the Perkins' journal (1843) frequently as Dunka.

(28) Maclean 1901: $\mathrm{x}$. This corresponds to 'subgroup C' in Takashina forthcoming.

(29) Jacobi 1973: 147 and 137.

(30) Maclean 1895: 74 note 1 says, in addition, 'It is never thus pronounced, and should be .... prîqé wâ.' Now it turns out that this holds good in the case of Urmi.

(31) The name is given as 'Odischu (Merx 1873: Vorwort), Audischu (Socin 1882: vii) and 'Audíšô, (Nöldeke 1882: 669) for the name spelled in Syriac script 'Abdišō' 'Servant of Jesus'.

(32) Nöldeke 1882: 669.

(33) For the citation of Biblical texts see note (22). T stands for Merx' transcription of which 'ayn and e with a small circle under it are replaced by ' and $\check{e}$ respec. tively.

(34) bəbo is a colloquial word for the literary avo. Merx remarks (note 5, p. 58): Gewöhnl. Sprache statt des antiken Ausdrucks. He may have intended this whole phrase, not the choice of the word for 'father'. The 1966 edition has libbavoti 'hearts' for libbo.

(35) I write dismin because Oraham writes dish-min in spite of dizmin in Friedrich 1960: 22 (the form dizmin in the vocabulary p. 63 is an error). Maclean gives us both forms (1901: 71).

(36) Incidentally this transcription corroborates the generalization of this ending [et ed] to the plural nouns that end in - $i$ : yumánet Hiródus (for the text jumani $d$ Hirudis 'the days of Herod' Luke 1:5) and benâtet Ahrun (for bnoti d Ahrun 'the daughters of Aaron' do., $c f$. note 3 on p. 57). See Nöldeke: 1868: 149. 
(37) For his priority in the study of Ōdišū's language see Socin 1874: 598 and 1882: vii. He characterizes Merx' work as "sie ganz auf dem Standpunkte der gedruckten neusyrischen Literature steht." (ibid. note 2)

(38) "die Texte zuerst nach dem Gehör zu transcribiren und erst in zweiter Linie auch syrisch niederschreiben zu lassen.” (1882: vii) The part of Hoffmann's transcription in this work, however, does not reflect the ordinary speech of the informant since Hoffmann did the contrary to Socin's method (ibid.). In the following examples the text of Nestorian script Socin got after the transcription is given here in the 'New Alphabet' and T stands for his transcription. Numbers refer to those of the page and line.

(39) Just two examples from Hoffmann's Text I: pšítat hinnus 2: 7 (for $b$ şits $d$ Xinnus 1: 7 'in the year of Xinnus') and bšíkla dbarnáša 5: 1 (for b șikls $d$ barneșe $4: 1$ 'in the shape of man').

(40) Numbers refer to those of the proverbs in his study. His transcription is somewhat simplified. This phenomenon is touched upon by him on p. 6 , though slightly from a different viewpoint. Texts in the Nestorian script is reproduced here in the 'New Alphabet'.

(41) See Polotsky 1961 : 2-3. This article of Polotsky's deals with the 'New Alphabet' (pp. 6-11). In the short text of Osipoff (1913) I found only one instance; namely, for kul dana d tanjat (Polotsky 1967: 73) 'every time that she tells' he transcribes ['da:nu 't:'anjat']. Since this is not a proper case of the genitive construction, I have refrained from quoting instances of this kind thus far. But see below.

(42) Tsereteli 1965b: 229-30. The transcription is his, but the presentation of the type of construction is mine.

(43) Numbers refer to the page and line. The same phrase in the 'New Alphabet' orthography follows it.

(44) Maclean 1901: 21a and Oraham's dictionary p. 33b.

(45) Cerulli $1971: 1+25$.

(46) ibid. 1-24+28-31. This text has one instance worthy of mention but hard to explain: atrědeyán (Frasario 36), atrědeyána (37), atrâ deyanán (197) 'il nostro paese'. The first will be atra dijon 'our country' and we might find here [ed] for $\cdot a$ $d$, but nevertheless the rest have seemingly superfluous endings -a and -an. This leads one to conjecture that this forms one word or rather a composite word of one notion 'homeland', according to which the second is a normal masculine noun ending in -a while the third is a noun with the pronominal suffix of 1 st person plural -an (for the flat) 'our homeland'. This can explain the otherwise queer phonetic form. $C f$. deyyán (229) an ordinary form for dijan 'our'.

(47) Odisho 1988: 3-24.

(48) Nöldeke 1868: 148-9 and Tsereteli 1965b: 230.

(49) Tsereteli op. cit. 229. One example from Tsereteli's : àynịt da brāta (for *ajna $d d$-aho brato 'the eyes of this girl'). The doubling of $d$ is avoided in the 'New Alphabet'. See also Sabar 1976: 41 note 46.

(50) See Marogulov 1976: 41 and Takashina forthcoming section 3.9.

\section{References}

Cerulli, Enrico. 1971. Testi Neo-Aramaici dell'Iran Settentrionale, con Glossario di F

A. Pennacchietti I (Pubblicazioni del Seminario di Semitistica, Recerchi 8). Napoli.

Friedrich, Johannes. 1960. Zwei russische Novellen in neusyrischer Übersetzung und 
Lateinschrift (Abhandlungen für die Kunde des Morgenlandes, 33-4). Wiesbaden.

Hoberman, Robert D. 1989. The Syntax and Semantics of Verb Morphology in Modern Aramaic: A Jewish Dialect of Iraqi Kurdistan (American Oriental Series, 69). New Haven.

Jacobi, Heidi. 1973. Grammatik des thumischen Neuaramäisch (Nordostsyrien) (Abhand. lungen für die Kunde des Morgenlandes, 40-3). Wiesbaden.

Jastrow, Otto. 1971. "Ein neuaramäischer Dialekt aus dem Vilayet Siirt (Ostanatolien)." Zeitschrift der Deutschen Morgenländischen Gesellschaft 121: 215-22.

- 1988. Der neuaramäische Dialekt von Hertevin (Provinz Siirt) (Semitica Viva, 3). Wiesbaden.

Kampffmeyer, G. 1905. "Neusyrische Sprichwörter im Dialekt von Urmia." Mitteilungen des Seminars für Orientalischen Sprachen zu Berlin, II. Abt. (Westasiatische Studien): $1-24$.

Krotkoff, Georg. 1982. A Neo-Aramaic Dialect of Kurdistan: Texts, Grammar, and Vocabulary (American Oriental Series, 64). New Haven.

Maclean, Arthur John. 1895. Grammar of the Dialects of Vernacular Syriac. Cambridge. - 1901. Dictionary of the Dialects of Vernacular Syriac. Oxford. Reprint: 1972, Amsterdam.

Macuch, Rudolf. 1976. Geschichte der spät- und neusyrischen Literatur. Berlin.

Marogulov, Q.I. 1976. Grammaire néo-syriaque pour écoles d'adultes (dialecte d'Urmia). Trans. by O. Kapeliuk. (Comptes Rendus du Groupe Linguistique d'Études ChamitoSémitiques, Supplément, 5). Paris. (orig. ed. 1935, Moscow)

Merx, Adalbert. 1873. Neusyrisches Lesebuch. Texte im Dialecte von Urmia (Verzeichnis der Doctoren . . . Eberhard-Karls-Universitaet zu Tübingen . . . 1871 bis 1873). Tübingen.

Nöldeke, Theodor. 1868. Grammatik der neusyrischen Sprache am Urmia-See und in Kurdistan. Leipzig. Reprint: 1974, Hildesheim.

- 1882. Review of Socin 1882. Zeitschrift der Deutschen Morgenländischen Gesellschaft 36 : 669-82.

- 1883. Review of 'Les dialectes néo-araméens de Salamas par R. Duval. Paris, 1883.' Zeitschrift der Deutschen Morgenländischen Gesellschaft 37: 598-609.

Odisho, Edward Y. 1988. The Sound System of Modern Assyrian (Neo-Aramaic) (Semitica Viva, 2). Wiesbaden.

Osipoff, Sergius. 1913. “sürja'1t' (siriæk)." Le Mâ̂tre Phonétique 28: 79-80.

Perkins, Justin. 1843. A Residence of Eight Years in Persia among the Nestorian Christians. New York.

- 1862. Historical Sketch of the Mission to the Nestorians (printed together with the account of the Assyria Mission by Thomas Laurie, published by the American Board of Commissioners for Foreign Missions). New York.

Polotsky, Hans Jakob. 1961. "Studies in Modern Syriac." Journal of Semitic Studies 6 : $1-32$.

- 1967. "Eastern Neo-Aramaic: A) Urmi." In An Aramaic Handbook ed. by Franz Rosenthal (Porta Linguarum Orientalium, NS 10; 4 parts), II/1 [texts]: 69-77. Wiesbaden.

Rödiger, E. 1939. "Über die aramäische Vulgärsprache der heutigen syrischen Christen." Zeitschrift für die Kunde des Morgenlandes 2: 77-93.

Sabar, Yona. 1976. Pəšaṭ Wayəhî Bəšallaḥ. A Neo-Aramaic Midrash on Beshallah̆ (Exodus). Wiesbaden. 
Socin, Albert. 1874. Review of Merx 1873. Jenaer Literaturzeitung 38: 597-8. 1882. Die neu-aramaeischen Dialekte von Urmia bis Mosul. Tübingen.

Stoddard, D.T. 1856. "Grammar of the Modern Syriac Language as Spoken in Oroomiah, Persia, and in Koordistan." Journal of the American Oriental Society 5: 3-180h.

Takashina, Yoshiyuki. Forthcoming. "Some Remarks on Modern Aramaic of Hertevin." Journal of Asian and African Studies 40.

Tsereteli, К. 1965а. Материалы по Арамейской Диалектологии. Том I: Урмийский Диалект, Bыn. 1. Tbilisi.

1965b. "A Type of Nominal Syntagm in Modern Aramaic Dialects." Bulletin of the School of Oriental and African Studies 28:227-232. 